\title{
Field trial on glucose-induced insulin and metabolite responses in Estonian Holstein and Estonian Red dairy cows in two herds
}

\author{
Hanno Jaakson*, Katri Ling, Jaak Samarütel, Aire Ilves, Tanel Kaart, Olav Kärt
}

\begin{abstract}
Background: Insulin secretion and tissue sensitivity to insulin is considered to be one of the factors controlling lipid metabolism post partum. The objective of this study was to compare glucose-induced blood insulin and metabolite responses in Estonian Holstein ( $E H, n=14)$ and Estonian Red ( $E R, n=14)$ cows.

Methods: The study was carried out using the glucose tolerance test (GTT) performed at $31 \pm 1.9$ days post partum during negative energy balance. Blood samples were obtained at -15, -5, 5, 10, 20, 30, 40, 50 and 60 min relative to infusion of $0.15 \mathrm{~g} / \mathrm{kg}$ BW glucose and analysed for glucose, insulin, triglycerides (TG), non-esterified fatty acids (NEFA), cholesterol and $\beta$-hydroxybutyrate (BHB). Applying the MIXED Procedure with the SAS System the basal concentration of cholesterol, and basal concentration and concentrations at post-infusion time points for other metabolites, area under the curve (AUC) for glucose and insulin, clearance rate (CR) for glucose, and maximum increase from basal concentration for glucose and insulin were compared between breeds.

Results: There was a breed effect on blood NEFA $(P<0.05)$ and a time effect on all metabolites concentration $(P<0.01)$. The following differences were observed in EH compared to ER: lower blood insulin concentration 5 min after glucose infusion $(P<0.05)$, higher glucose concentration $20(P<0.01)$ and 30 min $(P<0.05)$ after infusion, and higher NEFA concentration before $(P<0.01)$ and 5 min after infusion $(P<0.05)$. Blood TG concentration in ER remained stable, while in $\mathrm{EH}$ there was a decrease from the basal level to the $40^{\text {th }}$ min nadir $(P<0.01)$, followed by an increase to the $60^{\text {th }}$ min postinfusion $(P<0.01)$.
\end{abstract}

Conclusion: Our results imply that glucose-induced changes in insulin concentration and metabolite responses to insulin differ between EH and ER dairy cows.

\section{Background}

Selection for higher milk production has been associated with changes in cows' metabolism, especially the capability to partition more energy into milk [1] and less into body reserves, and with enforced post partum lipid mobilization [2]. These changes have increased the incidence of a range of metabolic disorders such as fatty liver/ketosis complex and displaced abomasum [3], reduced cow fertility [4] and immunity [5]. Identifying the mechanisms that control lipid metabolism could help to develop strategies to improve cows' health and welfare, as well as fertility.

\footnotetext{
* Correspondence: hanno.jaakson@emu.ee

Institute of Veterinary Medicine and Animal Sciences, Estonian University of Life Sciences, 1 Kreutzwaldi St, 51006, Tartu, Estonia
}

In dairy cows, insulin and tissue sensitivity to insulin, which can be studied using an intravenous glucose infusion method, known as the glucose tolerance test (GTT), play a key role in the regulation of post partum nutrient partitioning and lipid mobilization [6]. At the beginning of lactation reduced blood glucose concentration is associated with relatively low blood insulin levels [7-9]. In addition, during the period of negative energy balance (NEB), lasting up to 70 days post partum [10], dairy cows show a weaker glucose-induced insulin response $[11,12]$ and reduced tissue sensitivity to insulin $[13,14]$ compared to the pre partum period. High producing cows have lower post partum blood insulin concentrations compared to less productive animals [15]. In addition, Holstein cows express stronger lipolytic responses to energy deficiency compared to Jersey cows 
[16] and have lower blood insulin concentrations and weaker insulin responses to glucose injection compared to beef cows $[17,18]$. These findings suggest that partitioning of energy between the tissues and milk, intensity of lipolysis, blood insulin level and insulin response to glucose injection could be related to cow breed.

In Estonia the average 305-day milk yield in 2008 was $7,577 \mathrm{~kg}$ in Estonian Holstein (EH) and 6,855 kg in Estonian Red (ER) cows [19]. We hypothesize that EH cows, as higher producers, may have a weaker insulin response and reduced sensitivity to antlipolytic and lipogenic effects of insulin compared to ER cows. Therefore, the aim of this study was to compare glucose-induced blood insulin and metabolite responses during the period of NEB in EH and ER cows.

\section{Methods}

\section{Farms, animals and experimental design}

The study was carried out on two similar management and high production level dairy farms during the housed period, in March and April 2005 on farm A and in February 2008 on farm B, on 28 clinically healthy multiparous $\left(2^{\text {nd }}\right.$ to $5^{\text {th }}$ parity) cows. Two experimental groups were formed as follows: $\mathrm{EH}(\mathrm{n}=14$; six cows from farm $\mathrm{A}$ and eight from farm B) and ER ( $\mathrm{n}=14$; eight cows from farm A and six from farm B). Cows' body weights $(\mathrm{BW})$ were $674 \pm 23 \mathrm{~kg}$ for $\mathrm{EH}$ and $583 \pm 22 \mathrm{~kg}$ for ER. On both farms cows were housed in tie stall barns and offered a total mixed ration (TMR) ad libitum twice a day, around 09.00 and 18.00. TMR samples were collected once a week throughout the whole experimental period and pooled. Feed values of TMR were calculated on the basis of the chemical composition of the ingredients, determined according to AOAC [20] methods in the pooled samples. TMR offered to the 15 to 150 days in milk feeding group, including the experimental cows, provided 11.4 MJ metabolizable energy (ME) and $96.6 \mathrm{~g}$ metabolizable protein (MP) per kg dry matter (DM) on farm $\mathrm{A}$, and 12.0 MJ ME and $105.5 \mathrm{~g} \mathrm{MP}$ per $\mathrm{kg} \mathrm{DM}$ on farm B (Table 1). Approximate DM intake (DMI) of the feeding group was about $22 \mathrm{~kg} / \mathrm{d}$ per cow on both farms and this was evaluated using a method appropriate for field conditions, as follows. On both farms, during the whole experimental period, the amount of TMR was weighed and on the basis of visual every day assessment of feed refusal, average DMI of the feeding group including experimental cows during the glucose tolerance test (GTT) was estimated per week. Cows were milked thrice a day; approximately from 05.00 to 08.00 , from 12.30 to 15.00 and from 20.00 to 23.00 on both farms. Average 305-day energy corrected milk (ECM) yield from the previous lactation in the experimental groups was $8,999 \pm 319 \mathrm{~kg}$ for $\mathrm{EH}$ and $8,253 \pm 287 \mathrm{~kg}$ for ER cows. ECM yields during the experiment,
Table 1 Ingredients and chemical composition of TMR on farms $A$ and $B$.

\begin{tabular}{|c|c|c|}
\hline & Farm A & Farm B \\
\hline \multicolumn{3}{|c|}{ Ingredients (\% DM) } \\
\hline Grass silage & 37.31 & 20.29 \\
\hline Corn silage & - & 15.91 \\
\hline Hay & 2.44 & 3.67 \\
\hline Barley meal & 14.08 & \\
\hline$\overline{\text { Corn meal }}$ & 23.23 & 9.64 \\
\hline Wheat meal & - & 9.62 \\
\hline Rape cake & 18.92 & 25.87 \\
\hline Soyabean meal & 2.58 & 7.56 \\
\hline Palm oil & - & 2.24 \\
\hline Brewers grains & - & 4.93 \\
\hline Mineral feed & 0.36 & 0.55 \\
\hline Limestone & 0.24 & 0.42 \\
\hline Salt & 0.57 & 0.42 \\
\hline Soda & - & 0.85 \\
\hline \multicolumn{3}{|c|}{ Chemical composition } \\
\hline Dry matter (\%) & 53.4 & 56.2 \\
\hline \multicolumn{3}{|l|}{ In dry matter } \\
\hline $\operatorname{NDF}(\mathrm{g} / \mathrm{kg})$ & 314.2 & 372.0 \\
\hline $\mathrm{ADF}(\mathrm{g} / \mathrm{kg})$ & 213.9 & 227.8 \\
\hline Crude protein $(\mathrm{g} / \mathrm{kg})$ & 164.5 & 197.5 \\
\hline Crude fat $(\mathrm{g} / \mathrm{kg})$ & 57.9 & 70.2 \\
\hline $\mathrm{Ca}(\mathrm{g} / \mathrm{kg})$ & 8.6 & 6.2 \\
\hline$\overline{P(g / k g)}$ & 5.1 & 5.3 \\
\hline $\mathrm{ME}(\mathrm{MJ} / \mathrm{kg})$ & 11.4 & 12.0 \\
\hline $\mathrm{MP}(\mathrm{g} / \mathrm{kg})$ & 96.6 & 105.5 \\
\hline
\end{tabular}

calculated as the mean of day before and day after GTT, were $36.8 \pm 2.6 \mathrm{~kg} / \mathrm{d}(\mathrm{EH})$ and $38.0 \pm 2.5 \mathrm{~kg} / \mathrm{d}(\mathrm{ER})$; mean milk constituents, determined by an infrared spectrometry (MilkoScan 4300, Foss Electric A/S, Slangerupgade 69,3400 Hillerød, Denmark), were $4.56 \pm 0.25 \%$ and $4.66 \pm 0.25 \%$ for fat, and $3.11 \pm 0.11 \%$ and $3.64 \pm$ $0.11 \%$ for protein in EH and ER respectively. Cow body condition scores (BCS) were evaluated by the same observer according to the method of Edmonson et al. [21] at calving and weekly up to the tenth week post partum.

The European Council Directive regarding the protection of animals and the Estonian Animal Protection Act have been complied with in this experiment. The study has been approved by the committee of animal experimentation of the Estonian Ministry of Agriculture.

\section{Glucose tolerance test}

The GTT was carried out according to the protocol described by Holtenius et al. [22] on average $31 \pm 1.9$ days post partum after the morning milking at around 
10.00 , on two to four cows on the same day. Feed was withdrawn $60 \mathrm{~min}$ before and during the GTT. A catheter (12G, Lenght $80 \mathrm{~mm}$; Jørgen Kruuse A/S, Havretoften 4, DK-5550 Langeskov, Denmark) was inserted into the jugular vein and fixed to the skin $30 \mathrm{~min}$ before the test. The catheter was filled with Li-heparin (LEO Pharma, Longwick Road, Princes Risborough, Buckinghamshire, HP27 9RR, United Kingdom) until the start of blood sampling and between samplings to avoid clotting. After infusion of $0.15 \mathrm{~g} / \mathrm{kg} \mathrm{BW}$ glucose (40\%-solution; Inj. Glucosi 40\%; Vetoquinol Biowet Sp. z o.o. ul. Kos. Gdyñskich 13-14 66-400, Gorzów Wlkp., Poland), for approximately $4 \mathrm{~min}$, the tubing and catheter were flushed with normal saline (Sodium Chloride 0.9\% I.V. Inf.; B. Braun Melsungen AG, Carl-Braun-Straße 1, 34212 Melsungen, Germany). Discarding the first portion, blood samples were collected into vacuum tubes with Li-heparin (BD Vacutainer Systems, NH 170 I.U., Plymouth, United Kingdom) at the following times: -15 , $-5,5,10,20,30,40,50$ and 60 min relative to the start of infusion. Plasma was separated by centrifugation (5000×g, $15 \mathrm{~min}$ ) immediately after sampling and kept at $-24^{\circ} \mathrm{C}$ until analysed.

\section{Analyses}

Concentrations of metabolites in plasma were analyzed spectrophotometrically (Helios $\beta$; Unicam Ltd., PO Box 206, York St., Cambridge, CB1 2ST, United Kingdom) using standard test kits (Human Gesellschaft für Biochemica und Diagonostica GmbH, Max-Planck-Ring 21 - D-65205 Wiesbaden, Germany) for glucose ( $\mathrm{mmol} / \mathrm{l})$, triglycerides (TG; mmol/l) and cholesterol (mg/dl); and test kits from Randox Laboratories Ltd. (Ardmore, Diamond Road, Crumlin, Co. Antrim, United Kingdom, BT29 4QY) for NEFA ( $\mu \mathrm{mol} / \mathrm{l})$ and $\beta$-hydroxybutyrate $(\mathrm{BHB} ; \mathrm{mmol} / \mathrm{l})$. Blood insulin concentration $(\mu \mathrm{IU} / \mathrm{ml})$ was measured radio-immunologically (Wallac 1470 Wizard Gamma Counter; Perkin Elmer Life and Analytical Sciences, Inc., 940 Winter Street, Waltham, Massachusetts 02451 USA) using ${ }^{125}$ I radioimmunoassay test kits (Coat-A-Count Insulin) from Siemens Medical Solutions Diagnostics (5210 Pacific Concourse Drive. Los Angeles, CA 90045-6900, USA). The inter- and intraassay coefficients of variation of the methods were below $6 \%$.

\section{Calculations and statistical analyses}

The following measurements in EH and ER cows were calculated and/or compared: BCS at calving and at the time of the GTT, and BCS loss from calving to GTT; cows BW and milk yield during the GTT; basal concentration of metabolites at the time of the GTT, calculated as means of pre-infusion samples; metabolite concentrations at each post-infusion time point; basal NEFA: cholesterol ratio; area under the curve (AUC) for glucose and insulin, calculated as the increment above basal concentration during the $60 \mathrm{~min}$ following glucose infusion; clearance rate (CR) for glucose, determined assuming first order kinetics using the model $\mathrm{Glc}_{\mathrm{t}}=\mathrm{Glc}_{\text {peak }} \times \mathrm{e}^{\mathrm{tCR}}$, including post-infusion peak of glucose concentration $\left(\mathrm{Glc}_{\mathrm{peak}}\right)$ and concentration at progressive time points $\left(\right.$ Glc $\left._{\mathrm{t}}\right)$; maximum increase for glucose and insulin, calculated as the difference between the basal concentration and the highest concentration. Comparisons of described variables of the breeds', except blood metabolites measured repeatedly, were performed according to a model considering discrete effects of breed and farm. To test the differences in blood metabolite concentrations between the breeds at different time points, and between selected time points within breeds, the proper contrasts were defined following the model:

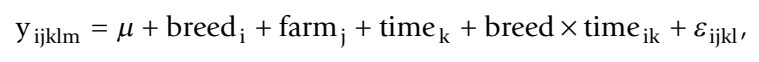

This model takes into account discrete effects of breed $\left(\right.$ breed $\left._{\mathrm{i}}\right)$, farm $\left(\right.$ farm $\left._{\mathrm{j}}\right)$, time point $\left(\right.$ time $\left._{\mathrm{k}}\right)$, breed and time point interaction and residual error $\left(\varepsilon_{\mathrm{ijk}}\right)$ with the nonzero covariance between the error terms corresponding to the observations of the same cow. The farm and time interaction effect and the linear effect of time from parturition to GTT were not statistically significant for any of the measured parameters and were omitted from the model. The characteristics of blood metabolites; BCS at calving, at GTT and BC loss; cows BW and ECM yield, and blood NEFA:cholesterol ratio during the GTT were compared according to the model, considering discrete effects of breed and farm. The models were analysed using the MIXED Procedure with the SAS System (version 9.1.3; SAS Institute Inc., Cary, NC).

Values given hereinafter are least square means presented with standard errors. Significance has been declared as follows: significant $(P \leq 0.01$ or $P \leq 0.05)$, tendency $(P \leq 0.1)$ and not significant $(P>0.1)$. The correction for multiple testing was made by the Bonferroni-Holm method.

\section{Results and discussion}

In this study we compared glucose-induced blood insulin and metabolite responses in two breeds one month after parturition. As reported previously, post partum $\mathrm{BC}$ loss and blood NEFA concentration correlate negatively with cows' energy balance [7]; the energy balance in our study was assessed using these indirect measures. BCS was lower in EH compared to ER at calving (3.27 \pm 0.12 and $3.50 \pm 0.12, P<0.05)$ and at the time of the GTT $(2.71 \pm 0.11$ and $3.02 \pm 0.11, P<0.05)$, while BC loss did not differ between breeds thus indicating that there was no difference in energy balance between the 
breeds. BCS decreased during the seven weeks post partum in both breeds, indicating that cows were in NEB during the GTT. On the other hand, blood NEFA basal concentration at the time of the GTT was higher in EH compared to ER $(795 \pm 85 \mu \mathrm{mol} / \mathrm{l}$ in $\mathrm{EH}$ and $569 \pm 85$ $\mu \mathrm{mol} / \mathrm{l}$ in ER, $P<0.01$; Figure 1), suggesting more intensive lipolysis, along with deeper NEB, at the time of the GTT in this breed.

There was a time effect on blood insulin concentration $(P<0.01)$; in response to glucose infusion insulin concentration in blood increased $(P<0.01)$ from basal infusion level by the $60^{\text {th }}$ min $(P<0.01$; Figure 1$)$. There were no significant differences between the breeds' blood insulin maximum increase and AUC (Table 2). After performing a Bonferroni-Holm correction the overall time effect as well as the increase of blood insulin from basal level to peak and following decrease to initial level remained significant in both breeds, while significant differences between the breeds disappeared. In both breeds glucose infusion led to an increase in blood glucose concentration from the basal level $(4.99 \pm 0.40 \mathrm{mmol} / \mathrm{l}$ in $\mathrm{EH}$ and $4.30 \pm 0.40 \mathrm{mmol} / \mathrm{l}$

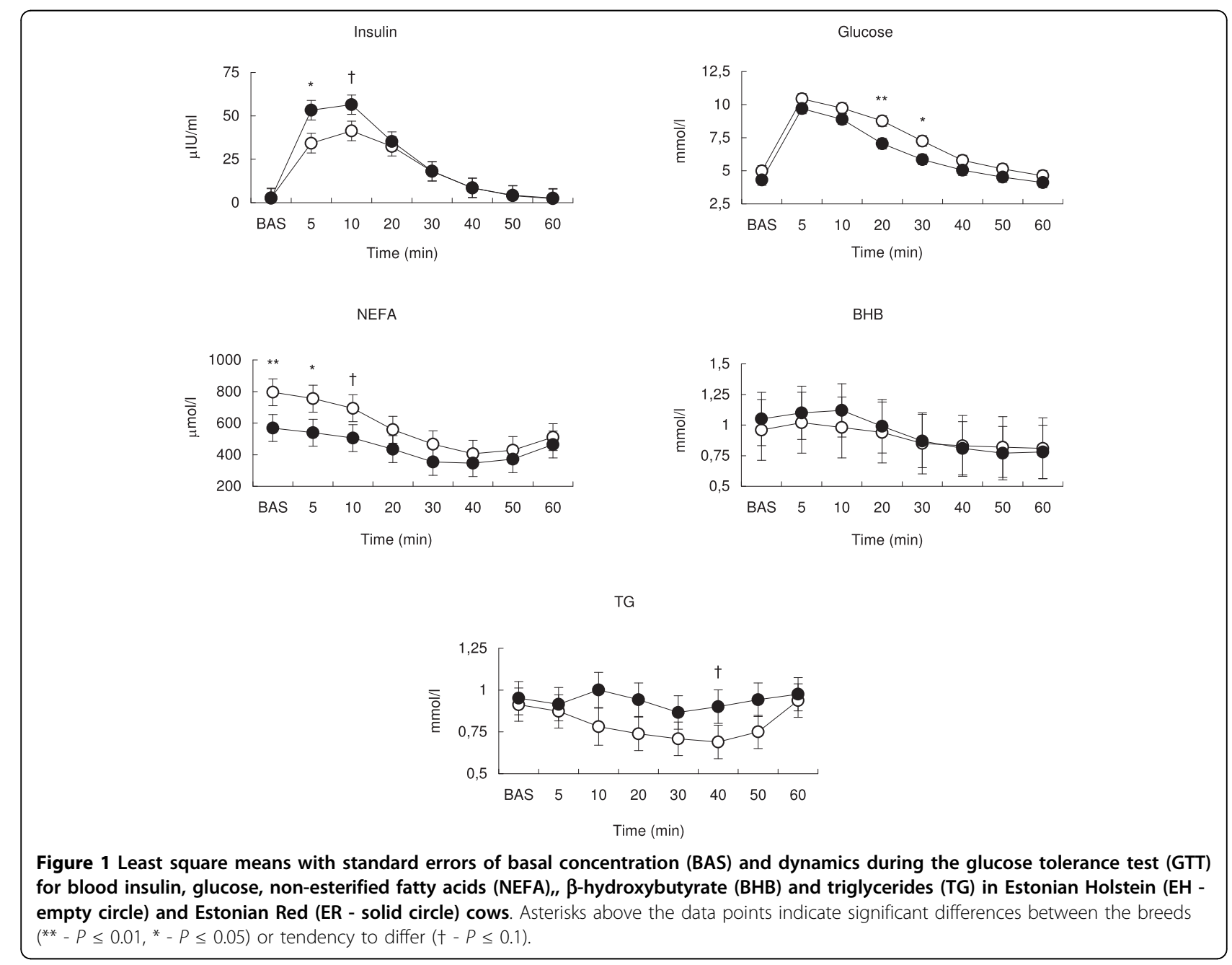

level $(2.8 \pm 5.6 \mu \mathrm{IU} / \mathrm{ml}$ in $\mathrm{EH}$ and $2.5 \pm 5.6 \mu \mathrm{IU} / \mathrm{ml}$ in ER) by the $5^{\text {th }}$ min postinfusion. At this time point it was lower in EH compared to ER $(34.2 \pm 5.6 \mu \mathrm{IU} / \mathrm{ml}$ in $\mathrm{EH}$ and $53.3 \pm 5.6 \mu \mathrm{IU} / \mathrm{ml}$ in ER, $P<0.05)$. Blood insulin reached peak level, which tended to be lower in $\mathrm{EH}$ compared to ER $(41.3 \pm 5.6 \mu \mathrm{IU} / \mathrm{ml}$ in $\mathrm{EH}$ and $56.5 \pm$ $5.6 \mu \mathrm{IU} / \mathrm{ml}$ in ER, $P<0.1$ ), at $10 \mathrm{~min}$ after infusion (Figure 1$)$. This was followed by a decrease to the pre- in ER) to the peak $(10.43 \pm 0.41 \mathrm{mmol} / \mathrm{l}$ in $\mathrm{EH}$ and 9.70 $\pm 0.40 \mathrm{mmol} / \mathrm{l}$ in ER) $5 \mathrm{~min}$ after infusion $(P<0.01)$. This was followed by a decrease to the pre-infusion level by the $60^{\text {th }}$ min $(P<0.01$; Figure 1$)$, which represented a time effect $(P<0.01)$. There was also tendency for a breed effect $(P<0.1)$ on blood glucose concentration; blood glucose was higher in $\mathrm{EH}$ compared to ER $20 \mathrm{~min}(P<0.01)$ and $30 \mathrm{~min}(P<0.05)$ after infusion 
Table 2 Least square means of glucose tolerance test (GTT) measurements for blood glucose and insulin in Estonian Holstein (EH) and Estonian Red (ER) cows.

\begin{tabular}{|c|c|c|c|c|}
\hline \multirow[b]{2}{*}{ Parameter } & \multicolumn{2}{|c|}{ Breed } & \multirow[b]{2}{*}{$\mathrm{SE}^{+}$} & \multirow[b]{2}{*}{$\mathrm{P}$} \\
\hline & $\overline{\mathrm{EH}}$ & ER & & \\
\hline \multicolumn{5}{|c|}{ Insulin } \\
\hline Maximum increase relative to basal concentration; $\mu \mathrm{lU} / \mathrm{ml}$ & 39.3 & 57.8 & 9.9 & 0.19 \\
\hline Area under the curve $(\mathrm{A} \cup C) ; \mu \mathrm{IU} / \mathrm{ml} \times \min$ & 875.3 & 1119.3 & 220.3 & 0.44 \\
\hline \multicolumn{5}{|c|}{ Glucose } \\
\hline Maximum increase relative to basal concentration; $\mathrm{mmol} / \mathrm{l}$ & 5.72 & 5.54 & 0.39 & 0.76 \\
\hline Area under the curve $(A \cup C) ; \mathrm{mmol} / \mathrm{I} \times \min$ & 122.87 & 104.15 & 10.41 & 0.22 \\
\hline Clearance rate $(\mathrm{CR}) ; \% / \mathrm{min}$ & 1.42 & 1.52 & 0.10 & 0.48 \\
\hline
\end{tabular}

t Due to the equal number of cows in breed groups the standard errors of least square means are the same for both breeds and only one value is shown

(Figure 1). There were no significant differences in blood glucose maximum increase, CR and AUC between the breeds (Table 2). Similarly to insulin the changes in blood glucose concentration within the breeds as well, as the overall time effect, remained significant after Bonferroni-Holm correction, while differences between the breeds persisted only at $20 \mathrm{~min}$. General dynamics of blood insulin and glucose during the GTT are in line with previous data $[17,18,22]$. In our study $\mathrm{EH}$ cows had higher NEFA levels in blood plasma indicating a more intense lipolysis compared to ER cows. According to Hammon et al. [12] reduced insulin secretion is associated with elongated glucose half-life and with higher milk yield at the time of the GTT in Holstein $\times$ Charolais F2 crossbreed cows 30 days post partum. In our study ECM yields between the breeds did not differ significantly.

However, during the GTT blood insulin remained lower in EH compared to ER at 5 and $10 \mathrm{~min}$, which was accompanied with higher blood glucose at 20 and 30 min (Figure 1) indicating less efficacious uptake of glucose by peripheral tissues in $\mathrm{EH}$. At the same time, in the lactating cow a large proportion of glucose is taken up independently of insulin by the mammary gland [23]; in our study this proportion was not distinguished from insulin-dependent uptake of glucose by adipose tissue and muscle.

In adipose tissue insulin reduces lipolysis by inhibiting hormone-sensitive lipase [24]. In our study, as in previous reports [25-27], a glucose-induced increase in insulin secretion in both breeds also led to a decrease in blood NEFA from the basal level $(795 \pm 85 \mu \mathrm{mol} / \mathrm{l}$ in $\mathrm{EH}$ and $569 \pm 85 \mu \mathrm{mol} / \mathrm{l}$ in ER) to a nadir (406 \pm 85 $\mu \mathrm{mol} / \mathrm{l}$ in $\mathrm{EH} ; 347 \pm 85 \mu \mathrm{mol} / \mathrm{l}$ in ER) at $40 \mathrm{~min}(P<$ 0.01 ) followed by an increase from this point onwards (Figure 1), which represented a time effect $(P<0.01)$. There was also a breed effect on blood NEFA concentration $(P<0.05)$ : compared to ER, the EH had higher basal concentration of blood NEFA $(P<0.01)$ and higher NEFA level 5 min after glucose-infusion $(P<$ 0.05); 10 min after infusion in EH NEFA tended to be higher compared to ER $(P<0.1$; Figure 1$)$. After Bonferroni-Holm correction the overall time effect on blood NEFA and the decrease of NEFA concentration from basal level to nadir remained significant in both breeds. Significant differences between the breeds disappeared; although a tendency to differ persisted for basal concentrations of blood NEFA. Observed blood NEFA dynamics in breeds possibly indicates a higher tendency towards basal lipolysis in adipose tissue in EH compared to ER. At the same time, on the basis of these results it remains unclear why the differences in blood NEFA concentrations between the breeds decreased during the GTT.

As the result of insulin-mediated inhibition of lipolysis and ketogenesis, blood $\mathrm{BHB}$ concentration decreased during the GTT in EH $(P<0.01)$ and ER cows $(P<$ 0.01 ; Figure 1$)$ with a time effect $(P<0.01)$. There was no significant difference between the breeds. Observed decrease remained significant after Bonferroni-Holm correction.

Blood TG basal concentration did not differ between the breeds $(0.91 \pm 0.10 \mathrm{mmol} / \mathrm{l}$ in $\mathrm{EH}$ and $0.95 \pm 0.10$ $\mathrm{mmol} / \mathrm{l}$ in ER). At the same time, during the GTT, ER cows' blood TG concentration was largely unchanged, while in $\mathrm{EH}$ cows there was a decrease from basal level to nadir $40 \mathrm{~min}$ after glucose infusion $(P<0.01)$, there being a tendency to breed differences at this time point $(0.69 \pm 0.10 \mathrm{mmol} / \mathrm{l} \mathrm{in} \mathrm{EH}$ and $0.90 \pm 0.10 \mathrm{mmol} / \mathrm{l}$ in ER, $P=0.1)$, followed by an increase to the $60^{\text {th }} \min (P$ $<0.01)$, revealing a time effect $(P<0.01$; Figure 1$)$. When adjusted by the Bonferroni-Holm correction, the tendency to breed differences at $40 \mathrm{~min}$ disappeared, while time effect on blood TG as well as changes in blood TG concentration within EH remained significant. In adipose tissue of non-ruminant species insulin has a stimulating effect on the activity of lipoprotein-lipase $[24,28]$, the enzyme hydrolysing TG within the complex 
of very low density lipoproteins, increasing uptake of fatty acids by adipocytes along with plasma triglyceride clearance [29]. As with adipose tissue, insulin has a stimulating effect on lipogenic enzymes in the liver $[24,30]$. We suggest, that during the GTT in ER cows the balance between insulin-stimulated plasma TG clearance and resynthesized TG release from the liver persisted but in EH cows it did not. As there is no evidence to support the idea of enhanced TG clearance in EH cows during the GGT we consider reduced insulin sensitivity of the liver explains the change in blood TG balance in $\mathrm{EH}$. This proposal of a possible decrease in hepatic lipogenesis of $\mathrm{EH}$ cows is supported by the following. First, the higher blood basal NEFA concentration in $\mathrm{EH}$ compared to ER $(P<0.01)$ could play a role. As stated previously, raised levels of blood NEFA may adversely influence insulin signalling in the liver [24], suppressing the lipogenic effect of insulin. Secondly, there is evidence of a relationship between hepatic lipidosis and reduced insulin sensitivity [31]; in addition, hepatic lipidosis is related to decreased packaging and secretion of triglycerides in the liver [32].

According to Holtenius [33] a raised blood NEFA:cholesterol ratio is considered to be a marker of hepatic lipidosis. In our study EH cows had higher NEFA:cholesterol ratios $(3.4 \pm 0.4$ in $\mathrm{EH}$ and $2.2 \pm 0.2$ in ER, $P<$ $0.05)$ compared to ER, suggesting the possibility of a greater expression of hepatic lipidosis in $\mathrm{EH}$ cows. Therefore we suggest that the decrease in blood TG concentration during the GTT could be attributed to less intensive resynthesis and release of TG from the liver of the EH cows.

\section{Conclusion}

In our study less pronounced glucose-induced increase in blood insulin concentration was accompanied by higher blood glucose concentrations in $\mathrm{EH}$ compared to ER cows. In response to glucose-induced insulin secretion lipolysis in adipose tissue and ketogenesis in the liver were reduced during the GTT in both breeds. Blood TG concentration in EH during the GTT decreased, while in ER the TG level remained largely unchanged.

\footnotetext{
Abbreviations

AUC: area under the curve; BCS: body condition score; BHB: $\beta$ hydroxybutyrate; BW: body weight; CR: clearance rate; DIM: days in milk; DM: dry matter; DMI: dry matter intake; ECM: energy corrected milk; EH: Estonian Holstein; ER: Estonian Red; GTT: glucose tolerance test; ME: metabolizable energy; MP: metabolizable protein; NEB: negative energy balance; NEFA: non-esterified fatty acids; TG: triglycerides; TMR: total mixed ration.
}

\section{Acknowledgements}

Ministry of Education and Research (SF 0170165s08) and the Ministry of Agriculture and Estonian Science Foundation (ETF 5422) for financial support, Mrs. Ülle Lätt for technical assistance, Dr. David Arney for linguistic correction and all who have been involved are gratefully acknowledged. We also thank the staff of Põlula Katsefarm and AS Tartu Agro for their kind cooperation.

\section{Authors' contributions}

All authors participated in designing the study, interpreting the data and compiling the manuscript. HJ carried out the study, compiled the data and drafted the manuscript. KL helped to draft the manuscript. JS and Al carried out the study, TK performed the statistical analyses and OK coordinated the study. All authors read and approved the final manuscript.

\section{Competing interests}

The authors declare that they have no competing interests.

Received: 14 October 2009

Accepted: 20 January 2010 Published: 20 January 2010

\section{References}

1. Agnew RE, Yan $\mathrm{T}$ : Impact of recent research on energy feeding systems for dairy cattle. Livestock Production Science 2000, 66:197-215.

2. Beerda B, Ouweltjes W, Sebek LBJ, Windig JJ, Veerkamp RF: Effects of genotype by environment interactions on milk yield, energy balance, and protein balance. Journal of Dairy Science 2007, 90:219-228.

3. Goff JP: Major advances in our understanding of nutritional influences on bovine health. Journal of Dairy Science 2006, 89:1292-1301.

4. Wathes DC, Bourne N, Cheng Z, Mann GE, Taylor VJ, Coffey MP: Multiple correlation analyses of metabolic and endocrine profiles with fertility in primiparous and multiparous cows. Journal of Dairy Science 2007, 90:1310-1325.

5. Overton TR, Waldron MR: Nutritional management of transition dairy cows: strategies to optimize metabolic health. Journal of Dairy Science 2004, 87(E suppl):E105-E119.

6. Bell AW, Bauman DE: Adaptations of glucose metabolism during pregnancy and lactation. Journal of Mammary Gland Biology and Neoplasia 1997, 2:265-278.

7. Doepel L, Lapierre $H$, Kennelly JJ: Peripartum performance and metabolism of dairy cows in response to prepartum energy and protein intake. Journal of Dairy Science 2002, 85:2315-2334

8. Jaakson H, Ling K, Kaldmäe H, Samarütel J, Kaart T, Kärt O: Influence of prepartum feeding on periparturient metabolic status in Estonian Holstein cows. Veterinarija ir Zootechnika 2007, 40:14-21.

9. Patton RS, Sorenson CE, Hippen AR: Effects of dietary glucogenic precursors and fat on feed intake and carbohydrate status of transition dairy cows. Journal of Dairy Science 2004, 87:2122-2129.

10. Jorritsma R, Wensing T, Kruip TAM, Vos PLAM, Noordhuizen JPTM: Metabolic changes in early lactation and impaired reproductive performance in dairy cows. Veterinary Research 2003, 34:11-26.

11. Bossaert P, Leroy JLMR, De Vliegher S, Opsomer G: Interrelations between glucose-induced insulin response, metabolic indicators, and time of first ovulation in high-yielding dairy cows. Journal of Dairy Science 2008, 91:3363-3371.

12. Hammon HM, Bellmann O, Voigt J, Schneider F, Kühn C: Glucosedependent insulin response and milk production in heifers within a segregating resource family population. Journal of Dairy Science 2007, 90:3247-3254.

13. Guesnet PM, Massoud MJ, Demarne Y: Regulation of adipose tissue metabolism during pregnancy and lactation in the ewe: the role of insulin. Journal of Animal Science 1991, 69:2057-2065.

14. Sasaki S: Mechanism of insulin action on glucose metabolism in ruminants. Animal Science Journal 2002, 73:423-433.

15. Sartin JL, Cummins RJ, Kemppainen DNM, Rahe CH, Williams JC: Glucagon, insulin, and growth hormone responses to glucose infusion in lactating dairy cows. American Journal of Physiology - Endocrinology and Metabolism 1985, 248(E suppl):E108-E114.

16. Theilgaard P, Friggens NC, Sloth KH, Ingvartsen KL: The effect of breed, parity and body fatness on the lipolytic response of dairy cows. Animal Science 2002, 75:209-219.

17. Pareek N, Voigt J, Bellmann O, Schneider F, Hammon HM: Energy and nitrogen metabolism and insulin response to glucose challenge in lactating German Holstein and Charolais heifers. Livestock Science 2007, 112:115-122. 
18. Shingu H, Hodate K, Kushibiki S, Ueda Y, Watanabe A, Shinoda M, Matsumoto M: Breed differences in growth hormone and insulin secretion between lactating Japanese Black cows (beef type) and Holstein cows (dairy type). Comparative Biochemistry and Physiology Part C: Toxicology \& Pharmacology 2002, 132:493-504.

19. Estonian Animal Recording Centre: Results of Animal recording in Estonia. 2007http://www.jkkeskus.ee/english/sisu/aastaraamat_2008.pdf.

20. Association of official analytical chemists (AOAC): Official methods of analyses. AOAC International. Gaithersburg Washington MD, 182005.

21. Edmonson $A J$, Lean $L$, Weaver $L D$, Farver $T$, Webster GA: Body condition scoring chart for Holstein dairy cows. Journal of Dairy Science 1989, 73:68-78.

22. Holtenius $K$, Agenäs S, Delavaud C, Chilliard Y: Effects of feeding intensity during the dry period. 2. Metabolic and Hormonal Responses. Journal of Dairy Science 2003, 86:883-891.

23. van Knegsel ATM, Brand van den H, Graat EAM, Dijkstra J, Jorritsma R, Decuypere E, Tamminga S, Kemp B: Dietary Energy Source in Dairy Cows in Early Lactation: Metabolites and Metabolic Hormones. Journal of Dairy Science 2007, 90:1477-1485.

24. Lewis GF, Carpentier A, Adeli K, Giacca A: Disordered fat storage and mobilization in the pathogenesis of insulin resistance and type 2 diabetes. Endocrine Reviews 2002, 23:201-229.

25. Boston RC, Roche JR, Ward GM, Moate PJ: A novel minimal model to describe non-esterified fatty acid kinetics in Holstein dairy cows. Journal of Dairy research 2008, 75:13-18.

26. Lemosquet S, Rideau N, Rulquin H, Faverdin P, Simon J, Verite R: Effects of a duodenal glucose infusion on the relationship between plasma concentrations of glucose and insulin in dairy cows. Journal of Dairy Science 1997, 80:2854-2865.

27. Pires JAA, Pescara JB, Brickner AE, Silva del Rio N, Cunha AP, Grummer RR: Effects of abomasal infusion of linseed oil on responses to glucose and insulin in holstein cows. Journal of Dairy Science 2008, 91:1378-1390.

28. Greco D, Stabenfeldt GH: Endocrinology. Textbook of veterinary physiology Philadelphia: WB Saunders CompanyGunningham JG , 3 2002, 360-363.

29. Fielding BA, Frayn KN: Lipoprotein lipase and the disposition of dietary fatty acids. British Journal of Nutrition 1998, 80:495-502.

30. Hayirli A: The role of exogenous insulin in the complex of hepatic lipidosis and ketosis associated with insulin resistance phenomenon in postpartum dairy cattle. Veterinary Research Communications 2006, 30:749-774

31. Lucy MC, Jiang H, Kobayashi Y: Changes in the somatotrophic axis associated with the initiation of lactation. Journal of Dairy Science 2001, 84(E suppl):E113-119E.

32. Bobe G, Young JW, Beitz DC: Invited review: Pathology, etiology, prevention, and treatment of fatty liver in dairy cows. Journal of Dain Science 2004, 87:3105-3124.

33. Holtenius P: Plasma lipids in normal cows around partus and in cows with metabolic disorders with and without fatty liver. Acta Veterinaria Scandinavica 1989, 30:441-445.

doi:10.1186/1751-0147-52-4

Cite this article as: Jaakson et al.: Field trial on glucose-induced insulin and metabolite responses in Estonian Holstein and Estonian Red dairy cows in two herds. Acta Veterinaria Scandinavica 2010 52:4.

\section{Submit your next manuscript to BioMed Central and take full advantage of:}

- Convenient online submission

- Thorough peer review

- No space constraints or color figure charges

- Immediate publication on acceptance

- Inclusion in PubMed, CAS, Scopus and Google Scholar

- Research which is freely available for redistribution

Submit your manuscript at www.biomedcentral.com/submit
Biomed Central 